\title{
Analysis of the Natural Disasters in the Last Century and the People Who Were Consequently Displaced
}

\author{
Seher Palanbek Yavaş̧ ${ }^{1}$ iD , Caner Baysan² ${ }^{2}$ iD , Ayşe Emel Önal ${ }^{1}$ (iD
}

1 Department of Public Health, Division of Environmental Health, University of İstanbul and Medicine Faculty, İstanbul, Turkey

${ }^{2}$ Department of Public Health, Division of Epidemiology, University of Ankara and Medicine Faculty, Ankara, Turkey

\section{Seher PALANBEK YAVAS}

Caner BAYSAN

Ayşe Emel ÖNAL

This study was presented at the 4th International, 22nd National Public Health Congress.

Correspondence: Caner Baysan Department of Public Health, Division of Epidemiology, University of Ankara and Medicine Faculty, Ankara, Turkey

Phone: +905057792642

E-mail: canerbaysan@gmail.com

$\begin{array}{ll}\text { Received } & : 5 \text { May } 2021 \\ \text { Accepted } & : 140 \text { ctober } 2021\end{array}$

\section{ABSTRACT}

Purpose: Natural Disasters are complex events which expose people to various risks and dangers.

Methods: The data for our research, which was designed to be a descriptive one, was obtained from Emergency Events Database (EM-DAT) and Internal Displacement Monitoring Centre (IDMC) database. Target population of our study consists of 287,913,123 people who were displaced in consequence of 15,406 natural disasters which occurred in the world between the years of 1920 (January) - 2020 (August) and natural disasters which occurred between the years 2008 (January) - 2019 (December).

Results: It was determined that in the 5 continents examined (Africa, America, Asia, Europe, Oceania), there has been a rapid growth in hydrological and meteorological disasters after the year 1980. On the other hand, with regards to displacements due to disasters, flood and storm related disasters were determined to cause displacement more than others.

Conclusion: Ultimately, the natural disasters related to the climate change have increased over the years and caused displacement, death, and financial damage.

Keywords: Natural Disasters, Displacement People, Climatological Disasters

\section{Son Yüzyılda Meydana Gelen Afetler ve Yerinden Edilen Kişilerin Analizi}

ÖZET

Amaç: Doğal afetler, insanların çok sayıda risk ve tehlikeye maruz kaldığı karmaşık olaylardır.

Gereç ve yöntem: Tanımlayıcı tipte tasarlanmış araştırmamııın verileri EM-DAT (Emergency Events Database) ve IDMC (Internal Displacement Monitoring (entre) veri tabanından alınmıştır. Çalışmamızın evrenini, EM-DAT veri tabanında yer alan 1920 (0cak)-2020 (Ağustos) yılları arasında dünyada meydana gelen 15.406 farklı doğal afetler ve 2008 (0cak)-2019 (Aralık) yılları arasında doğal afetlerden kaynaklı 287.913.123 yerinden edilen kişiler oluşturmaktadır.

Bulgular: Incelenen 5 kıtada 1980 sonrasında (Afrika, Amerika, Asya, Avrupa, Okyanusya) hidrolojik ve meteorolojik afetlerde hızlı bir artış olduğu tespit edilmiştir. Afetlerden kaynaklı yerinden edilmeler afet alt grupları şeklinde incelendiğinde ise; sel ve fırtınadan kaynaklı afetlerin diğerlerine göre daha fazla yerinden edilmeye neden olduğu saptanmıştır.

Sonuç: Sonuç olarak yıllar içerisinde iklim değişikliği ile ilgili afetler artarak yerinden edilme, ölüm ve maddi hasara sebep olmuştur.

Anahtar Kelimeler: Doğal Afetler, Yerinden Edilen Kişiler, Klimatolojik Afetler 
A disaster may be defined as an unexpected incident which exceeds local capacity, requires national or international aid, causes either death or injury for people, results in loss of property, affects the society economically and socially and threatens the security, spoils its functionality, and often occurs due to natural reasons, however may also occur due to human related causes (1-3).

On the other hand, natural disasters are caused by hydrometeorological, climatic, geophysical, and biological incidents (e.g., earthquake, landslide, tsunami, windstorm, flood, or drought) which affect the natural and built environment of the region affected (Table 1) (1).

\begin{tabular}{|c|c|c|}
\hline Category & Sub-category & Type \\
\hline Geophysical & Geophysical & $\begin{array}{l}\text { Earthquake, mass movement, } \\
\text { volcanic activity, tsunamis, } \\
\text { rockfall, }\end{array}$ \\
\hline Meteorological & Weather-related & $\begin{array}{l}\text { Storm, extreme temperature, } \\
\text { fog }\end{array}$ \\
\hline Hydrological & & Flooding, landslide, wave action \\
\hline Climatological & & $\begin{array}{l}\text { Drought, wildfire, glacial lake } \\
\text { outburst }\end{array}$ \\
\hline Biological & & $\begin{array}{l}\text { Epidemic, Insect infestation, } \\
\text { animal accident }\end{array}$ \\
\hline
\end{tabular}

Natural disasters are complex incidents which expose people to many risks and dangers. Each disaster scenario is unique in its own way and presents new and unusual difficulties both for the victims and the rescue emergency personnel. Negative result of disasters in people's lives is the situation of migration from the region where the disaster occurred to another location. Displacement within the context of disasters is a global and increasing phenomenon. According to a study conducted by the Internal Displacement Monitoring Center (IDMC), since 2008, natural disasters have caused displacement of approximately 24,6 million people each year (this equals to one person per second) (2). Displacement due to natural disasters is defined as "Situations where people are forced or coerced to leave their homes or places of habitual residence as a result of a disaster or to avoid the effects of an urgent and predictable natural disaster"(3). Majority of this sort of displacements are caused by a limited number of megadisasters. Among the latest examples are the combination of earthquake, tsunami, and nuclear disaster in Japan; big floods in Australia and Pakistan; big forest fires in Greece and Russia; droughts in China and East Africa; and a catastrophic earthquake in Haiti. Climatic changes are expected to have a stronger effect on populations movements as well. In a date as early as 1990, Intergovernmental Climate Change Panel has warned about how human migration might become the ultimate effect of the climate change (4). People who get displaced due to natural disasters face similar difficulties with those who escape from conflict and violence. Many lose their homes, properties, and income, and their access to basic needs and services such as water, food, health, and education reduces, and they also face with interruption of social networks (5).

In this study, we wanted to make an assessment of the natural disasters that occurred in the last century and people who were consequently displaced.

\section{MATERIALS AND METHODS}

The data of our descriptive study was taken from the Emergency Events Database (EM-DAT) and IDMC (Internal Displacement Monitoring Center). EM-DAT is one of the databases of the non-profit organization with an international status called The Center for Research on the Epidemiology of Disasters (CRED) within the Université Catholique de Louvain (UCL) School of Public Health in Brussels. It is a reliable data source that keeps the types of disasters occurring in countries and the effects of these disasters on people (death, injury, material damage, etc.) with a historical and specific systematic. According to this database, in order for an event to be considered as a disaster, at least one of the criteria for the death of at least 10 people, affecting at least 100 people, declaration of a state of emergency and international calls for assistance by the relevant state must have been fulfilled (6). IDMC, on the other hand, as part of the Norwegian Refugee Council (NRC) and working internationally since its establishment in 1998, has been providing data and analysis of internal displacement. They work with national governments, UN agencies and expert centers to find effective and durable solutions to internal displacement issue (7).The universe of our study consists of 15,406 natural disasters that occurred in the world between 1920 (January) -2020 (August) in the EM-DAT database. Natural disasters are composed of "Biological, Climatological, Geophysical, Hydrological, Meteorological" main groups in the EM-DAT database. In the IDMC database, it is classified as Geophysical and Weather-related (including climatological, hydrological and meteorological disasters). The distribution of the main and subgroups of Natural Disasters is shown in Table 1. It consists of $287,913,123$ internally displaced persons due to natural disasters between the years 2008 (January) -2019 (December). Disasters and displacements at different times and places; disaster subgroups are grouped on the basis of years (decades), continents and countries. The data are presented as frequency distributions and 
calculated using the Statistical Package for the Social Sciences (SPSS) 25.0 package program.

\section{RESULTS}

It was determined that a total of 15,406 natural disasters occurred in the world between 1920 and 2020. Of natural disasters, $39.1 \%$ were hydrological $(n=6,025), 31.8 \%$ meteorological $(n=4,894), 11.2 \%$ geophysical $(n=1,732)$, $10.2 \%$ biological $(n=1,577)$, and $7.6 \%$ climatological $(n=$ $1,178)$ disasters. When disaster groups are examined on the basis of subgroups, the most occurring subgroup among hydrological disasters is flood $(n=5,267)$ with $34.2 \%$, the most occurring subgroup among meteorological disasters is storm ( $n=4,296$ ) with $27.9 \%$, the most occurring subgroup among geophysical disasters is earthquake ( $\mathrm{n}$ $=1,445$ ) with $9.4 \%$, the most occurring subgroup of biological disasters is epidemic with $9.6 \%(n=1,481)$, the most occurring subgroup among the climatological disasters is determined as drought $(n=733)$ with $4.8 \%$. In addition, among all disaster subgroups, wildfire $2.9 \%$, volcanic activities $1.6 \%$, Insect infestation $0.6 \%$, Mass movement (dry) $0.3 \%$, Animal accident $0.01 \%$, Fog $0.01 \%$ were found to be the least common disaster types in 1920-2020 (Figure 1).

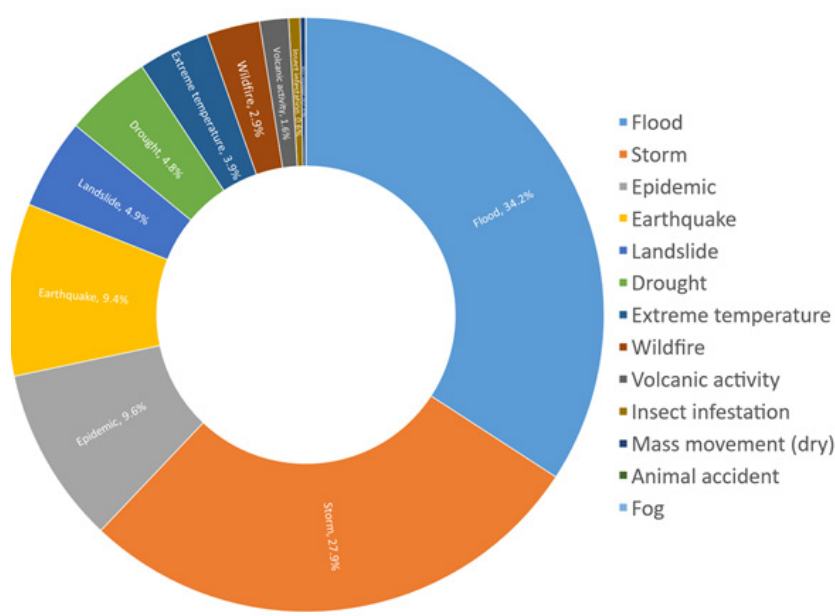

Figure 1. Distribution of Natural Disasters Subgroups that Occurred in the World between 1920-2020

When the natural disasters are evaluated in terms of the disaster group over time, there are less than 50 disasters per year in terms of natural disaster types until 1980. After 1980 , a rapid increase was found in hydrological and meteorological disasters. In addition, it is noteworthy that two different peaks occurred in the early 2000s in terms of biological disasters (Figure 2).

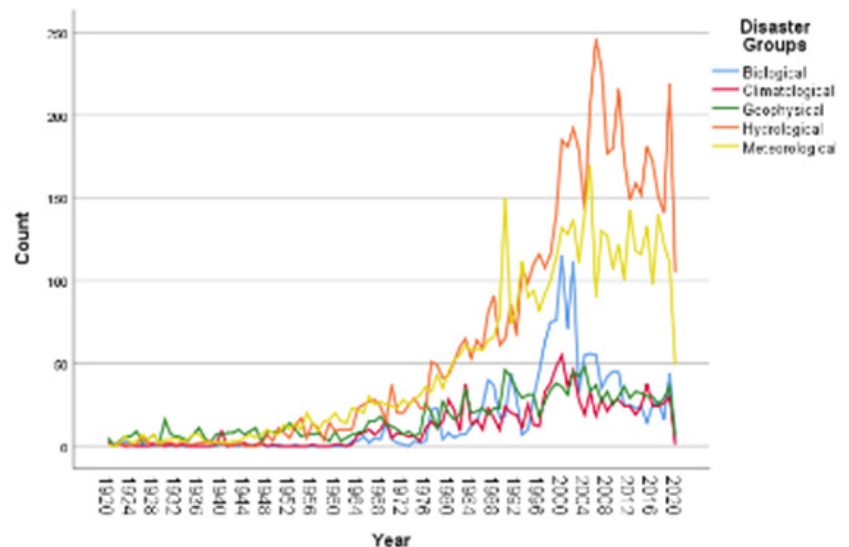

Figure 2. Time Curve Graph of Natural Disasters that Occurred in the World between 1920-2020

When the situation of the continents in the last 10 decades according to disaster types is evaluated; the rate of increase in hydrological and meteorological disasters in the last two decades in the five continents studied is remarkable. In addition, it is seen that the number of disasters in the Asian continent is more than the other four continents in terms of geophysical and hydrological disaster types. It is observed that biological disasters are more common in Africa than other continents (Figure 3).

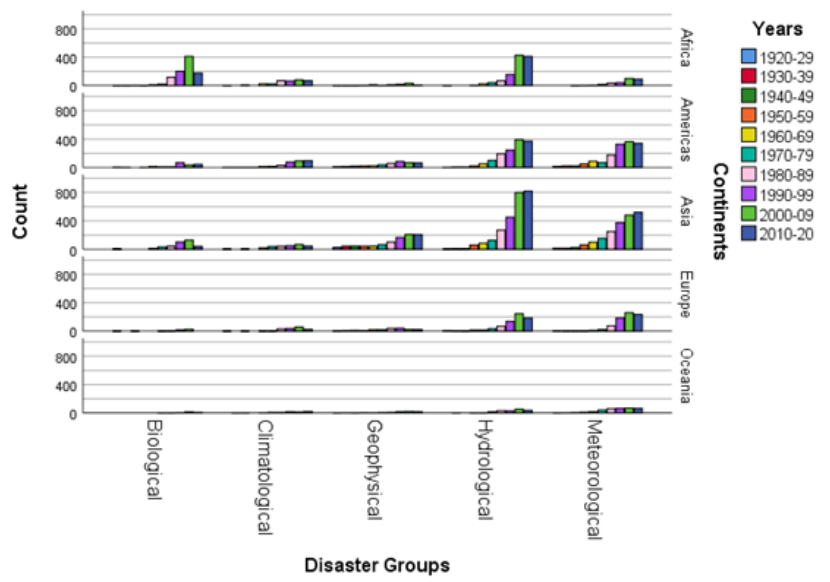

Figure 3. Frequency of Natural Disasters that Occurred in the World between 1920-2020 in Continents by Decades 
When the shares of total financial damage caused by disaster types in the last 100 years in total financial damage caused by natural disasters are examined, it is seen that it constitutes $44.7 \%$ of meteorological disasters. It is seen that the type of disaster that has the largest share in terms of death is climatological disasters with $42.2 \%$. In terms of death / material damage ratio, biological disasters have the highest rate with 1,460 times, while meteorological disasters them last place with a rate of 0.1 (Figure 4).

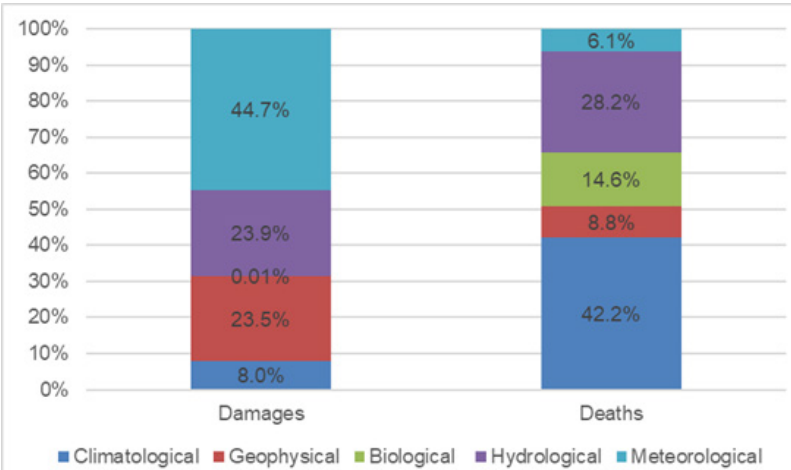

Figure 4. Share of Natural Disaster Types that Occurred in the World between 1920-2020 in Total Financial Damage (\$) and the Share of Deaths

When we compare the share of deaths and material damage of disasters in the last 100 years in particular for continents; It is seen that the continents where geophysical disasters have the largest share in property damage are Africa, Asia, and Oceania. Hydrological disasters seem to have the greatest impact on the European continent in terms of material damage. In the American continent, meteorological disasters have the biggest share in property damage. It is seen that climatological disasters in Africa, Asia, and Europe and Geophysical disasters in America and Oceania have the largest share in terms of their share in total deaths (Table 2).
When we look at the countries where natural disasters are most common, we see that they are America $(n=1,019)$, China $(\mathrm{n}=947)$ and India $(\mathrm{n}=734)$.

A total of $287,913,123$ people were internally displaced between 2008-2019. The highest number of displacement was in $2008(n=38,240,828)$, in $2010(n=42,349,514)$ and in 2012 ( $n=30,145,960)$; The least displacement occurred in $2011(n=15,015,954)$ (Figure 5).

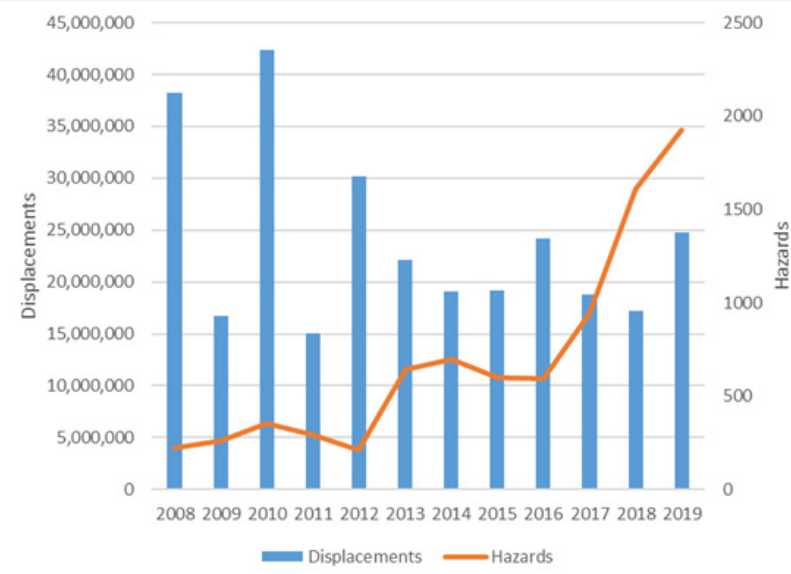

Figure 5.Distribution of People Internally Displaced and Hazards Occurred in the World between 2008-2019 by Years

When internal displacements (according to database classification) are divided into weather-related displacement and geophysical displacement; It was determined that the most displacement was related to weather-related $(n=253,199,368 ; 87.9 \%)$. When we examine the subgroups of weather-related displacement; It was determined that people were internally displaced mostly due to floods $(\mathrm{n}=142,029,072 ; 56.0 \%)$, storm $(\mathrm{n}=104,656,593 ; 41.3 \%)$ and drought $(n=2,320,529 ; 0.9 \%)$.

Table 2. Distribution of Natural Disaster Types in the World between 1920-2020 in Material Damage and Death of Disaster Types by Continents

\begin{tabular}{|c|c|c|c|c|c|c|c|c|c|c|}
\hline & \multicolumn{5}{|c|}{ Damages (\$) (\%) } & \multicolumn{5}{|c|}{ Deaths (\%) } \\
\hline Continents & 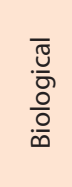 & 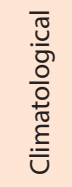 & 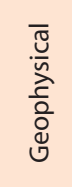 & 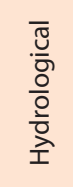 & 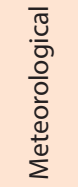 & 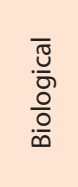 & $\begin{array}{l}\overline{0} \\
\frac{0}{\bar{O}} \\
\frac{0}{0} \\
\frac{0}{0} \\
\stackrel{\Xi}{U}\end{array}$ & 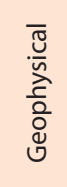 & 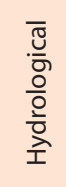 & 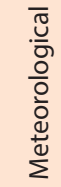 \\
\hline Africa & $<0.1$ & 19.9 & 34.4 & 25.3 & 20.3 & 26.3 & 67.8 & 2.1 & 3.1 & 0.7 \\
\hline Americas & $<0.1$ & 9.8 & 8.0 & 10.3 & 71.9 & 3.8 & 0.1 & 62.9 & 18.1 & 15.1 \\
\hline Asia & $<0.1$ & 4.6 & 37.7 & 33.6 & 24.1 & 15.4 & 39.6 & 7.2 & 31.9 & 5.8 \\
\hline Europe & $<0.1$ & 10.5 & 21.4 & 37.3 & 30.9 & $<0.1$ & 77.9 & 10.2 & 1.7 & 10.1 \\
\hline Oceania & 0.1 & 19.6 & 32.0 & 18.4 & 29.8 & 3.5 & 7.6 & 64.6 & 7.1 & 17.2 \\
\hline
\end{tabular}


Table 3. Distribution of Subgroups of Weather-Related Internal Displacements (Air-related Displacement) by Years between $2008-2019$ in the World

\begin{tabular}{|c|c|c|c|c|c|c|c|c|c|}
\hline \multirow[b]{2}{*}{ Years } & \multicolumn{8}{|c|}{ Whethear Related Displacements } & \multirow[b]{2}{*}{ Total } \\
\hline & Flood & Storm & Drought & Wildfire & $\begin{array}{c}\text { Extreme } \\
\text { temperature }\end{array}$ & $\begin{array}{l}\text { Wet mass } \\
\text { movement }\end{array}$ & $\begin{array}{c}\text { Mass } \\
\text { movement }\end{array}$ & $\begin{array}{c}\text { Severe } \\
\text { winter } \\
\text { condition }\end{array}$ & \\
\hline 2008 & $11.5 \times 10^{6}$ & $10.0 \times 10^{6}$ & * & $50 \times 10^{3}$ & $0.8 \times 10^{6}$ & $30 \times 10^{3}$ & * & $*$ & $22.5 \times 10^{6}$ \\
\hline 2009 & $7.4 \times 10^{6}$ & $7.8 \times 10^{6}$ & * & $8.3 \times 10^{3}$ & $20 \times 10^{3}$ & $20 \times 10^{3}$ & * & * & $15.2 \times 10^{6}$ \\
\hline 2010 & $36.2 \times 10^{6}$ & $2.0 \times 10^{6}$ & * & $16 \times 10^{3}$ & * & $0.8 \times 10^{6}$ & * & * & $38.3 \times 10^{6}$ \\
\hline 2011 & $10.3 \times 10^{6}$ & $3.1 \times 10^{6}$ & * & $4.3 \times 10^{3}$ & $90 \times 10^{3}$ & $0.4 \times 10^{6}$ & * & * & $13.9 \times 10^{6}$ \\
\hline 2012 & $19.8 \times 10^{6}$ & $9.6 \times 10^{6}$ & * & $60 \times 10^{3}$ & 3,507 & $50 \times 10^{3}$ & * & * & $29.5 \times 10^{6}$ \\
\hline 2013 & $6.1 \times 10^{6}$ & $14.1 \times 10^{6}$ & * & $90 \times 10^{3}$ & $10 \times 10^{3}$ & $5 \times 10^{3}$ & $*$ & * & $20.3 \times 10^{6}$ \\
\hline 2014 & $8.2 \times 10^{6}$ & $9.1 \times 10^{6}$ & * & $50 \times 10^{3}$ & 6 & $60 \times 10^{3}$ & * & * & $17.4 \times 10^{6}$ \\
\hline 2015 & $8.3 \times 10^{6}$ & $6.3 \times 10^{6}$ & * & $90 \times 10^{3}$ & 1,231 & $44 \times 10^{3}$ & 4.891 & 807 & $14.7 \times 10^{6}$ \\
\hline 2016 & $10.2 \times 10^{6}$ & $12.9 \times 10^{6}$ & * & $0.3 \times 10^{6}$ & $90 \times 10^{3}$ & 2.485 & * & * & $23.5 \times 10^{6}$ \\
\hline 2017 & $8.6 \times 10^{6}$ & $7.5 \times 10^{6}$ & $1.3 \times 10^{6}$ & $0.5 \times 10^{6}$ & $5 \times 10^{3}$ & $20 \times 10^{3}$ & * & * & $18.0 \times 10^{6}$ \\
\hline 2018 & $5.4 \times 10^{6}$ & $9.3 \times 10^{6}$ & $0.8 \times 10^{6}$ & $0.4 \times 10^{6}$ & $20 \times 10^{3}$ & $20 \times 10^{3}$ & $*$ & * & $16.1 \times 10^{6}$ \\
\hline 2019 & $9.9 \times 10^{6}$ & $13.0 \times 10^{6}$ & $0.3 \times 10^{6}$ & $0.5 \times 10^{6}$ & $20 \times 10^{3}$ & $60 \times 10^{3}$ & $*$ & * & $23.9 \times 10^{6}$ \\
\hline 2008-2019 & $142.0 \times 10^{6}$ & $104.7 \times 10^{6}$ & $2.3 \times 10^{6}$ & $2.1 \times 10^{6}$ & $1.1 \times 10^{6}$ & $1.0 \times 10^{6}$ & 4.891 & 807 & $253.2 \times 10^{6}$ \\
\hline
\end{tabular}

It was determined that internal displacement caused by forest fires has increased rapidly since 2016 . Geophysical Internal Displacements accounted for $12.9 \%$ ( $n=34,713,446)$ of displacements. When the subgroups of geophysical internal displacements were examined, it was found that earthquakes $(n=33,381,177 ; 96.2 \%)$ and volcanic eruptions ( $n=1,208,515 ; 3.5 \%)$ caused the most internal displacement (Table 4).
When we examine the internal displacement caused by natural disasters on the basis of continents between 2008 and 2019, it is calculated that it is the most common in Africa (27.2\%), Asia (23.0\%), America (22.0\%). While the internal displacements in the continents of Africa, Europe, and Oceania are mostly based on weather-related; it is seen that geophysical internal displacements come to the fore in America and Asia (Table 5).

Table 4. Distribution of Geophysical Displacements by Subgroups in the World between 2008-2019

\begin{tabular}{|c|c|c|c|c|c|c|c|}
\hline \multirow[b]{2}{*}{ Years } & \multicolumn{6}{|c|}{ Geophsical Displacements } & \multirow[b]{2}{*}{ Total } \\
\hline & Earthquake & $\begin{array}{l}\text { Volcanic } \\
\text { eruption }\end{array}$ & $\begin{array}{l}\text { Dry mass } \\
\text { movement }\end{array}$ & Volcanic activity & $\begin{array}{l}\text { Wet mass } \\
\text { movement }\end{array}$ & $\begin{array}{c}\text { Mass } \\
\text { movement }\end{array}$ & \\
\hline 2008 & $15.7 \times 10^{6}$ & $50 \times 10^{3}$ & $20 \times 10^{3}$ & * & * & * & $15.7 \times 10^{6}$ \\
\hline 2009 & $1.4 \times 10^{6}$ & $60 \times 10^{3}$ & 991 & * & * & $*$ & $1.5 \times 10^{6}$ \\
\hline 2010 & $3.7 \times 10^{6}$ & $0.4 \times 10^{6}$ & * & * & * & * & $4.0 \times 10^{6}$ \\
\hline 2011 & $1.1 \times 10^{6}$ & $10 \times 10^{3}$ & * & * & * & * & $1.1 \times 10^{6}$ \\
\hline 2012 & $60 \times 10^{3}$ & $40 \times 10^{3}$ & 80 & * & * & * & $0.7 \times 10^{6}$ \\
\hline 2013 & $1.8 \times 10^{6}$ & $50 \times 10^{3}$ & 500 & * & * & * & $1.8 \times 10^{6}$ \\
\hline 2014 & $1.5 \times 10^{6}$ & $0.2 \times 10^{6}$ & 2,772 & * & * & * & $1.7 \times 10^{6}$ \\
\hline 2015 & $4.4 \times 10^{6}$ & * & * & $30 \times 10^{3}$ & 4,049 & 183 & $4.5 \times 10^{6}$ \\
\hline 2016 & $0.7 \times 10^{6}$ & $20 \times 10^{3}$ & $10 \times 10^{3}$ & * & * & * & $0.7 \times 10^{6}$ \\
\hline 2017 & $0.6 \times 10^{6}$ & $0.2 \times 10^{6}$ & $10 \times 10^{3}$ & * & * & 12 & $0.8 \times 10^{6}$ \\
\hline 2018 & $0.9 \times 10^{6}$ & $0.2 \times 10^{6}$ & $20 \times 10^{3}$ & * & * & 1,000 & $1.1 \times 10^{6}$ \\
\hline 2019 & $0.9 \times 10^{6}$ & $20 \times 10^{3}$ & 2,858 & * & * & 150 & $0.9 \times 10^{6}$ \\
\hline $2008-2019$ & $33.4 \times 10^{6}$ & $1.2 \times 10^{6}$ & $0.09 \times 10^{6}$ & $30 \times 10^{3}$ & 4,049 & 1,345 & $34.7 \times 10^{6}$ \\
\hline
\end{tabular}


Table 5. Distribution of Internal Displacement Types by Continents between 2008-2019 in the World

\begin{tabular}{|c|c|c|c|c|}
\hline Continent & & $\begin{array}{l}\text { Weather related } \\
\text { Displacements }\end{array}$ & $\begin{array}{l}\text { Geophysical } \\
\text { Displacements }\end{array}$ & Total Displacements \\
\hline \multirow{2}{*}{ Africa } & Sum & $23.1 \times 106$ & $0.08 \times 106$ & $23.2 \times 106$ \\
\hline & $\%$ of Total $n$ & $27.2 \%$ & $23.3 \%$ & $27.2 \%$ \\
\hline \multirow{2}{*}{ Americas } & Sum & $25.8 \times 106$ & $6.2 \times 106$ & $32.1 \times 106$ \\
\hline & $\%$ of Total $n$ & $22.0 \%$ & $23.30 \%$ & $22.0 \%$ \\
\hline \multirow{2}{*}{ Asia } & Sum & $202.9 \times 106$ & $28.1 \times 106$ & $231.0 \times 106$ \\
\hline & $\%$ of Total $n$ & $23.0 \%$ & $34.2 \%$ & $23.0 \%$ \\
\hline \multirow{2}{*}{ Europe } & Sum & $0.7 \times 106$ & $0.2 \times 106$ & $0.9 \times 106$ \\
\hline & $\%$ of Total $n$ & $18.30 \%$ & $11.0 \%$ & $18.3 \%$ \\
\hline \multirow{2}{*}{ Oceania } & Sum & $0.6 \times 106$ & 127257 & $0.8 \times 106$ \\
\hline & $\%$ of Total $n$ & $9.4 \%$ & $8.2 \%$ & $9.4 \%$ \\
\hline \multirow{2}{*}{ Total } & Sum & $253.2 \times 106$ & $34.7 \times 106$ & $287.9 \times 106$ \\
\hline & $\%$ of Total $n$ & $100.0 \%$ & $100.0 \%$ & $100.0 \%$ \\
\hline
\end{tabular}

When the countries are examined in terms of the number of internal displacements; it was found that displacements due to natural disasters are the most common in China ( $n=81,672,141)$, India $(n=44,657,133)$ and Philippines $(n=43,563,870)$.

\section{DISCUSSION}

The frequency and intensity of natural disasters are gradually increasing. In our study, a rapid increase in hydrological and meteorological disasters was found after 1980. According to a published report (1980-2008), it has been found that hydrological and meteorological disasters increased rapidly compared to geophysical disasters; although the relationship between climate change and natural disasters is not fully understood, the frequency of natural disasters due to climate has increased. Examples of deadly climate-related disasters include the massive floods in Thailand in 2011, Hurricane Sandy in the United States in 2012, and Typhoon Haiyan in the Philippines in 2013 (8). Similar to our study, it was determined in previous studies that Asia was the region most affected by floods, which accounts for approximately $50 \%$ of flood deaths in the last quarter of the 20th century $(9,10)$. The frequency and impacts of floods are expected to increase due to population increases, economic growth and climate change (11).

In our study, it was determined that the most common subgroup of meteorological disasters was storm with $27.9 \%$. In a published report, it was determined that 396 disasters and 95 million people were affected in 2019, it was stated that storms that made up 35\% of the total and affected the highest number of people. Of the 91 storms that occurred in the last year (2019), the 2 deadliest storms; Hurricane Idai affected Mozambique and Zimbabwe (March, over 1200 deaths), and the Dorian storm affected the United States and the Bahamas (September, at least 358 deaths) (12).

In our study, it can be said that the geophysical activity in the Asian continent is relatively high compared to other continents. As an example of major earthquakes in Asia; Tangshan earthquake in China in 1976, the Great Hanshin-Awaji earthquake in Japan that occurred in 1995, 2011 and Tohoku Earthquake can be shown (12-14). It was determined that 1.8 million people were left homeless and 65,000 to 300,000 people died in the earthquake that occurred in 2010 in Haiti, which is an island country in the Caribbean Sea in the United States, which also has a great impact (14-16).

In our study, the most common subgroup of biological disasters was epidemic with 9.6\%. The Spanish flu epidemic in the first decades of the twentieth century (1918-1920) was the first truly global epidemic, and it was also the first epidemic to occur in the modern medical environment where specialties such as infectious diseases and epidemiology had developed $(17,18)$. The first epidemic of the twenty-first century was the Severe Acute Respiratory Syndrome (SARS) epidemic that started in China in 2002. It was reported that the epidemic caused 8,422 cases and 916 deaths in 37 countries (19). In our study, 2 peaks observed in biological disasters in the 2000s; it can be attributed to the SARS and H1N1 outbreaks. In addition, in our study, it was determined that biological epidemics are more common in the African continent. Following the first 
Ebola virus case reported in 1970 in Africa, the frequency of recognizable outbreaks increased especially in subSaharan Africa in the 1990s, and the most severe epidemic was documented in 2014; around 14,100 cases have been reported worldwide, causing about 5,200 deaths (overall mortality rate $37 \%)(20)$.

In our study, when we examine the subgroups of weather related displacement, where the most displacement is caused by Weather related disasters; It was determined that people were mostly displaced due to flood $(56 \%)$, storm (41.3\%) and drought (0.9\%). In a published report, it was determined that between 2008 and 2014, a total of 184.4 million people were displaced due to disasters, and an average of 26.4 million people each year, and the vast majority of these people, such as 22.5 million, were displaced due to weather and climate-related disasters $(3,21)$. In another study, it was determined that 16.1 million of 17.2 million displacement cases that occurred in 2018 were due to weather-related disasters (displacement due to, respectively; 9.3 million storm, 5.4 million floods, and 764,000 draughts), while 1.1 million were due to geophysical related disasters $(915,000$ earthquakes and 186,000 volcanic eruptions) (22).In our study, most displacement cases were seen in 2010. Major disasters seen this year include floods that destroyed millions of homes in China and Pakistan, torrential rains associated with El Niño in Latin America and the Caribbean, and a devastating earthquake in Haiti. The earthquake in Haiti alone caused 1.5 million people to become homeless (22).

\section{Limitations}

In our study, we examined natural disasters (1920-2020) and displaced persons (2008-2019) that occurred in a certain time period. Since we could not find these two types of data in the same organization's database, we used the databases of two different organizations. This is due to the fact that statistics on displaced persons that have started to be kept can be considered new. Unfortunately, the knowledge of the displaced people does not go back a century. This may be considered as a limitation of our study.

\section{CONCLUSION}

Weather-related hazards account for more than 87 percent of all disaster displacements, and the effects of climate change and increasing population density in regions exposed to storms and floods mean more and more people are affected. Including disaster resilience in national growth strategies for each country, budget allocation, careful and logical urban management (physical planning, environmental planning), national planning for climate crisis returns are precautions to increase the resilience of the people to disasters and reduce their vulnerability.

\section{Ethical considerations}

To conduct the present study, the ethical principles for medical research on human subjects established by the Declaration of Helsinki were followed. Istanbul University Clinical Research Ethics Committee was endorsed this study as in Minutes No. 218949.

\section{REFERENCES}

1. Internal Displacement Monitoring Centre (IDMC). Disaster Dataset Codebook Definition of IDP 2015 [online]. Available at: https:// www.internal-displacement.org/sites/gidd/idmc-disaster-datasetcodebook-2017-05-22.pdf. Accessed February 21, 2021.

2. Centre for Criminal Justice and Human Rights (CCJHR). Disaster Risk Reduction Information Sheet International Disaster Law project 2018 [online]. Available at: http://media.ifrc.org/ifrc/wpcontent/uploads/sites/5/2018/03/IDL-Information-Sheet-No.2-DRRFebruary-2018.pdf. Accessed January 12, 2021.

3. The Nansen Inciative. The Nansen Initiative Global Consultation 2015; [online].Available at: https://www.nanseninitiative.org/wpcontent/uploads/2015/02/GLOBAL-CONSULTATION-REPORT.pdf. Accessed January 12, 2021.

4. International Peace Institute (IPI) [Internet].Disasters and Displacement: Improving Preparedness and Protection 2012 [online]. Available at: https://www.ipinst.org/wp-content/uploads/ publications/ipi_e_pub_disasters.pdf. Accessed January 12, 2021.

5. Oliver-Smith A. Disasters and Large-Scale Population Dislocations: International and National Responses. Oxford Research Encyclopedia of Natural Hazard Science 2018 p: 1-40 [online]. Available at: https:// doi.org/10.1093/acrefore/9780199389407.013.224. Accessed January 12, 2021.

6. Emergency Events Database (EM-DAT) [Internet].Classification for Natural Disasters. [online]. Available at: https://www.emdat.be/ classification\#Geophysical. Accessed October 10, 2020.

7. Internal Displacement Monitoring Centre (IDMC) About us 2020 [online]. Available at: https://www.internal-displacement.org/ about-us. Accessed October 10, 2020.

8. Thomas V, López R. Global Increase in Climate-Related Disasters. Asian Development Bank. [online]. 2015; Vol. 466. Available at: http://hdl.handle.net/11540/5274. Accessed October 10, 2020.

9. Jonkman SN, Kelman I. An analysis of the causes and circumstances of flood disaster deaths. Disasters 2005;29(1):75-97. doi: 10.1111/j.0361-3666.2005.00275.x.

10. Doocy S, Daniels A, Murray S, Kirsch TD. The Human Impact of Floods: a Historical Review of Events 1980-2009 and Systematic Literature Review. PLoS Curr 2013;1-29. DOI: 10.1371/currents.dis. f4deb457904936b07c09daa98ee8171a

11. Winsemius HC, Aerts JCJH, Van Beek LPH, Bierkens MFP, Bouwman $A$, Jongman $B$, et al. Global drivers of future river flood risk. Nat Clim Chang 2016;6(4):381-5.

12. Ritchie H. Natural Disasters. Our Worl in Data [online]. Available at: https://ourworldindata.org/natural-disasters. Accessed October 10, 2020. 
13. Wang J, Yang J, Li B. Pain of disasters: The educational cost of exogenous shocks evidence from Tangshan Earthquake in 1976. China Econ Rev 2017;46:27-49.

14. Hatakana T. The Great East Japan Earthquake: Research and actions of Japan Medical Association Research Institute. Japan Med Assoc J 2012;55(5):368-74.

15. Oluwafemi JO, Ofuyatan OM, Sadiq OM, Oyebisi SO, Abolarin JS, Babaremu KO. Review of world earthquakes. Int J Civ Eng Technol 2018;9(9):440-64.

16. Lu X, Bengtsson L, Holme P. Predictability of population displacement after the 2010 Haiti earthquake. Proc Natl Acad Sci U S A 2012;109(29):11576-81. DOI: 10.1073/pnas.1203882109

17. Flecknoe D, Charles Wakefield B, Simmons A. Plagues \& wars: the 'Spanish Flu' pandemic as a lesson from history. Med Confl Surviv 2018;34(2):61-8. DOI: 10.1080/13623699.2018.1472892

18. Huremović D. Brief History of Pandemics (Pandemics Throughout History). Psychiatry of Pandemics 2019;7-35. doi: 10.1007/978-3-030-15346-5_2

19. Tatar B, Adar P. SARS-CoV-2: Mikrobiyology and Epidemiology. J TepecikEduc Res Hosp 2020;30:27-35. DOI: 10.5222/terh.2020.34392

20. Kalra S, Kelkar D, Galwankar SC, Papadimos TJ, Stawicki SP, Arquilla B, et al. The Emergence of Ebola as a Global Health Security Threat: From 'Lessons Learned' to Coordinated Multilateral Containment Efforts. J Glob Infect Dis 2014;6(4):164-77.

21. Internal Displacement Monitoring Centre, (IDMC), Global Estimates 2015: People displaced by disasters [online] Available at: https:// www.internal-displacement.org/sites/default/files/inlinefiles/20150713-global-estimates-2015-en-v1.pdf. Accessed October 10, 2020.

22. Ponserre S, Ginnetti J. Disaster Displacement: A Global Review, 2008-2018. IDMC [online] Available at: https://reliefweb.int/sites/ reliefweb.int/files/resources/201905-disaster-displacement-globalreview-2008-2018.pdf. Accessed October 10, 2020. 